\title{
ANALISIS INVESTASI KAWASAN HIJAU BERDASARKAN GREENSHIP NEIGHBORHOOD V.1.0 (Studi Kasus Istana Kaliwates Regency)
}

\author{
Anik Ratnaningsih ${ }^{1)}$, Hurrin Ufiantara ${ }^{2)}$, Willy Kriswardhana ${ }^{3)}$ \\ Jurusan Teknik Sipil Universitas Jember \\ email: anik.teknik@unej.ac.id ${ }^{1)}$, ufiantara.hurrin@gmail.com ${ }^{2)}$, willy.teknik@unej.ac.id ${ }^{3)}$
}

DOI: http://dx.doi.org/10.29103/tj.v11i1.344

(Received: July 2020 / Revised: December 2020 / Accepted: December 2020)

\begin{abstract}
Abstrak
Kawasan perumahan merupakan solusi untuk menciptakan pemukiman yang lebih tertata di wilayah kota dan sekitarnya, namun memiliki tantangan berupa penggunaan energi dan air yang besar, pengelolaan kawasan, dan penyediaan fasilitas untuk penghuninya. Kawasan hijau dapat menjadi solusi untuk menjadikan kawasan perumahan berkelanjutan yang ramah lingkungan, efisien dalam penggunaan energi, dan memberi kemudahan bagi penghuninya. Penilaian yang digunakan pada penelitian ini yaitu penilaian kawasan hijau yang didasarkan pada perangkat penilaian Greenship Neighborhood V.1.0 oleh GBCI. Perencanaan pekerjaan peningkatan kawasan hijau dan penyusunan cash flow dilakukan setelah melakukan penilaian kawasan. Cash flow digunakan untuk melakukan analisis investasi yang menggunakan metode Net Present Value (NPV), Internal Rate of Return (IRR), Break Even Point (BEP), Payback Period (PBP), dan Profit Ability Index (PI). Hasil dari penelitian menunjukkan Net Present Value sebesar Rp12.917.114.905,- Internal Rate of Return sebesar 28,34\%, dan Profit Ability Index menunjukkan angka 1,592. Pengembalian modal yang dibutuhkan untuk mencapai Break Even Point adalah sebesar Rp73.184.818.841,- dengan penjualan minimum 68 unit rumah tipe 43/72, 74 unit rumah tipe 45/72, 19 unit rumah tipe 90/120, dan 5 unit ruko sedangkan Payback Period menunjukkan pengembalian dalam waktu 2 tahun.
\end{abstract}

Kata kunci: kawasan hijau, analisis investasi, perumahan

\begin{abstract}
A residential area is a solution for creating organized settlements in the city, but have problems of large amounts of energy and water usage, area management, and facilities provided for its inhabitants. Green areas can be a solution to make sustainable residential areas that are environmentally friendly, energy-efficient, and provide convenience for their inhabitants. The assessment used in this study is the Greenship Neighborhood V.1.0 assessment tool by GBCI. Green area improvement and cash flow are created after conducting the green area assessment. Cash flow is used to conduct investment analysis using methods of the Net Present Value (NPV), Internal Rate of Return (IRR), Break-Even Point (BEP), Payback Period (PBP), and Profit Ability Index (PI). The results of the study showed that the Net Present Value of Rp12,917,114,905, - the Internal Rate of Return of $28.34 \%$, and the Profit Ability Index showed an index number of 1.592 . The return on the capital needed to achieve the Break-Even Point is Rp73,184,818,841, with a minimum sales of 68 housing units of type 43/72, 74 housing units of type 45/72, 19 housing units of type 90/120, and 5 units of shophouses while Payback Period shows returns within 2 years.
\end{abstract}

Keywords: green area, investmen analysis, housing

Analisis Investasi Kawasan Hijau Berdasarkan Greenship Neighborhood V.1.0 (Studi Kasus Istana Kaliwates Regency) - Anik Ratnaningsih, Hurrin Ufiantara, Willy Kriswardhana 


\section{Latar Belakang}

Rumah merupakan sarana tempat tinggal yang digunakan dalam jangka waktu tertentu dan menjadi sarana sosial dalam ruang lingkup rumah (keluarga). Kelebihan pembangunan perumahan antara lain penggunaan lahan yang efisien, desain rumah yang sama sehingga menghemat biaya perancangan, dan perolehan keuntungan yang bisa didapat sebelum menyelesaikan keseluruhan area perumahan. Pengembang perumahan memiliki beberapa tantangan antara lain besarnya penggunaan energi listrik dan air, membutuhkan pengelolaan kawasan yang baik, menjaga fasilitas dan lingkungan yang nyaman bagi penghuninya. Faktor-faktor tersebut menuntut para pengembang untuk menciptakan konsep yang dapat menangani masalah tersebut, salah satunya konsep kawasan hijau.

Kawasan perumahan hijau dapat diartikan sebagai kawasan perumahan berkelanjutan yang bertujuan untuk menciptakan kawasan perumahan yang ramah lingkungan, efisien dalam penggunaan energi dan air, baik dalam pengelolaan kawasan, kemudahan dalam akses dan gerak, dan memberi rasa nyaman untuk penghuninya. Indikator-indikator yang menentukan kawasan perumahan dapat diberi label 'green' dapat dilihat pada GBCI (Green Building Council Indonesia) di Greenship Neighborhood V.1,0.

Kawasan perumahan dalam studi penelitian ini, yaitu perumahan Istana Kaliwates Regency yang dikembangkan oleh oleh PT. Podo Tresno Sedoyo dan pembangunannya dilaksanakan oleh PT. Kinansyah Adhi Jaya Land serta berlokasi di Jl. Lumba-lumba, Kelurahan Kaliwates, Jember, Kabupaten Jember. Luas total perumahan ini yaitu $117.180 \mathrm{~m}^{2}$.

Berdasarkan penelitian yang dilakukan oleh Manggiasih, Hakim and Siswoyo (2019), dalam penilaian greenship terhadap perumahan Scientia Garden, menunjukkan bahwa kawasan tersebut telah memenuhi predikat Bronze menurut Greenship Neighborhood V.1.0. Ronim and Talidah (2019) juga telah melakukan penilaian kawasan hijau pada kawasan wisata Bandar Ecopark di Kabupaten Batang dan menunjukkan bahwa kawasan tersebut telah memenuhi predikat Silver. Sementara Aulia (2014), melakukan penilaian kawasan hijau dan analisis minat konsumen pada kawasan perumahan Citraland Surabaya. Penelitian tersebut menunjukkan bahwa kawasan Citraland Surabaya telah memiliki predikat Silver dan konsep kawasan hijau tidak membuat minat beli konsumen menjadi rendah. Ketiga penelitian tersebut menunjukkan bahwa perumahan yang menjadi obyek penelitian telah memenuhi kriteria kawasan hijau. Namun, sebagian besar kawasan perumahan di wilayah Jember masih belum memenuhi kriteria kawasan hijau berdasarkan Greenship Neighborhood, sehingga diperlukan adanya upaya peningkatan untuk memenuhi kriteria kawasan hijau.

Tujuan dari penelitian ini adalah untuk merencanakan upaya peningkatan kawasan menjadi kawasan berkonsep hijau beserta perencanaan investasinya. Dengan capaian tujuan penelitian ini, diharapkan dapat bermanfaat untuk membuka wawasan bagi mahasiswa maupun pengembang, serta dapat dijadikan masukan bagi pengembang dalam pelaksanaan konstruksi kawasan perumahan berikutnya.

Analisis Investasi Kawasan Hijau Berdasarkan Greenship Neighborhood V.1.0 (Studi Kasus Istana Kaliwates Regency) - Anik Ratnaningsih, Hurrin Ufiantara, Willy Kriswardhana 


\section{Metode Penelitian}

Penelitian ini dilakukan dalam waktu 6 (enam) bulan, yaitu sejak bulan Januari 2020 hingga bulan Juli 2020. Lokasi penelitian ini dilaksanakan pada kawasan perumahan Istana Kaliwates Regency yang berada di Jl. Lumba-lumba, Kelurahan Kaliwates, Jember, Kabupaten Jember. Lokasi perumahan Istana Kaliwates Regency seperti diperlihatkan pada Gambar 1.

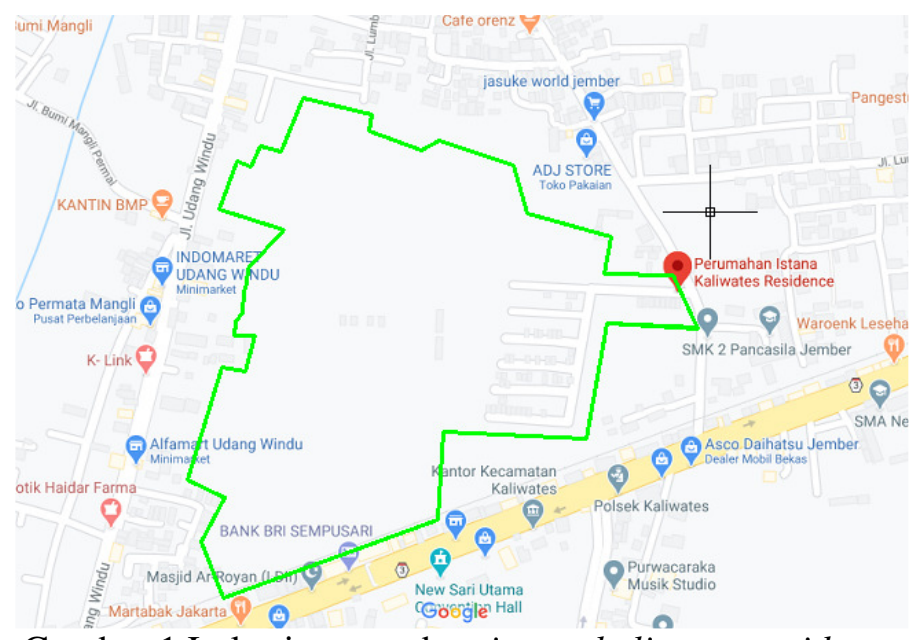

Gambar 1 Lokasi perumahan istana kaliwates residence

\subsection{Pengumpulan Data}

Pengumpulan data pada penelitian ini menggunakan metode literasi dan metode field research atau langsung pada lapangan. Jenis data yang digunakan pada penelitian ini adalah data primer dan data sekunder. Data tersebut antara lain: 1. Data primer berupa wawancara kepada pihak pengembang dan kuesioner minat beli kepada konsumen.

2. Data sekunder berupa site plan kawasan perumahan, perangkat penilaian Greenship Neighborhood V.1.0, dan AHSP Kabupaten Jember tahun 2019

\subsection{Analisis Data}

Analisis data yang digunakan adalah analisis kelayakan investasi dengan metode Net Present Value, Internal Rate of Return, Break Even Point, Payback Period, dan Profit Ability Index. Tahapan-tahapan pengerjaan penelitian ini akan dijabarkan sebagai berikut:

1. Penilaian Greenship pada kawasan dengan melakukan wawancara kepada pihak pengembang perumahan. Wawancara didasarkan pada perangkat penilaian Greenship Neighborhood.

2. Perencanaan peningkatan kawasan untuk mendapat predikat kawasan hijau dilakukan setelah menentukan peringkat hijau pada perumahan. Dari perhitungan ini dapat diketahui besar anggaran yang diperlukan untuk melakukan pekerjaan peningkatan kawasan hijau.

3. Penyusunan Cash Flow yang dapat dibuat setelah menentukan besar penjualan, Cash In-Flow dan Cash Out-Flow.

Analisis Investasi Kawasan Hijau Berdasarkan Greenship Neighborhood V.1.0 (Studi Kasus Istana Kaliwates Regency) - Anik Ratnaningsih, Hurrin Ufiantara, Willy Kriswardhana 
4. Analisis investasi dengan metode Net Present Value, Internal Rate of Return, Break Even Point, Payback Period, dan Profit Ability Index.

\subsection{Penilaian Greenship pada Kawasan}

Penilaian Greenship menggunakan perangkat penilaian yang didasarkan pada Greenship Neighborhood V.1.0 (Green Building Council Indonesia, 2015). Penilaian Greenship dilakukan dengan melakukan wawancara kepada seorang admin pengawas dari perumahan Istana Kaliwates Regency.

Hasil wawancara dengan pihak pengembang mengenai penilaian kawasan hijau diperlihatkan pada Tabel 1.

Tabel 1 Hasil wawancara penilaian greenship

\begin{tabular}{clc}
\hline No. & \multicolumn{1}{c}{ Kategori } & Skor \\
\hline 1. & Peningkatan Ekologi Lahan & 4 \\
\hline 2. & Pergerakan dan Konektivitas & 6 \\
\hline 3. & Manajemen dan Konservasi Air & 0 \\
\hline 4. & Limbah Padat dan Material & 6 \\
\hline 5. & Strategi Kesejahteraan Masyarakat & 7 \\
\hline 6. & Bangunan dan Energi & 2 \\
\hline
\end{tabular}

Dari hasil wawancara diketahui skor yang telah dicapai perumahan Istana Kaliwates Regency adalah 27 poin. Setelah mengetahui besar skor yang dicapai, maka peringkat greenship yang didapat dapat diketahui. Peringkat pada kawasan hijau tersebut berdasarkan Greenship Neighborhood V.1.0 seperti diperlihatkan pada Tabel 2.

Tabel 2 Peringkat kawasan hijau (Green Building Council Indonesia, 2015)

\begin{tabular}{ccc}
\hline Peringkat & Persentase Minimum & Skor Minimum \\
\hline Platinum & $73 \%$ & 90 \\
\hline Gold & $56 \%$ & 69 \\
\hline Silver & $47 \%$ & 58 \\
\hline Bronze & $35 \%$ & 43 \\
\hline
\end{tabular}

Skor yang didapat yaitu 27, karena kurang dari 43 (bronze) maka kawasan perumahan Istana Kaliwates Regency belum mendapat peringkat kawasan hijau.

\subsection{Perencanaan Peningkatan Peringkat Greenship}

Hasil penilaian menunjukkan bahwa perumahan Istana Kaliwates Regency belum mendapat peringkat greenship sehingga diperlukan adanya upaya perencanaan untuk peningkatan peringkat greenship. Pada penelitian ini dilakukan perencanaan peningkatan untuk mencapai kawasan perumahan hijau dengan peringkat bronze dengan skor minimum 43. Hasil wawancara menunjukkan bahwa skor awal perumahan telah mendapat skor 27 , sehingga dibutuhkan skor tambahan minimal 16 untuk mencapai peringkat bronze.

Adapun pekerjaan peningkatan yang akan direncanakan pada kawasan Istana Kaliwates Regency diperlihatkan pada Tabel 3.

Analisis Investasi Kawasan Hijau Berdasarkan Greenship Neighborhood V.1.0 (Studi Kasus Istana Kaliwates Regency) - Anik Ratnaningsih, Hurrin Ufiantara, Willy Kriswardhana 
Tabel 3 Pekerjaan peningkatan kawasan hijau

\begin{tabular}{lc}
\hline \multicolumn{1}{c}{ Pekerjaan } & Skor \\
\hline Penyediaan Ruang Terbuka Hijau (RTH). & $\mathrm{P}$ \\
Penyediaan RTH (25\% luas kawasan). & 3 \\
Penambahan tanaman lokal provinsi. & 2 \\
Membuat Studi tentang Aksesibilitas. & $\mathrm{P}$ \\
Pembuatan jalur pejalan kaki. & $\mathrm{P}$ \\
Menyediakan tempat parkir sepeda & 1 \\
Membuat diagram skematik air kawasan & $\mathrm{P}$ \\
Pembuatan pagar pembatas pada sungai. & 1 \\
Pembuatan Rencana pengelolaan sampah. & $\mathrm{P}$ \\
Pembuatan tempat sampah terpilah & $\mathrm{P}$ \\
Pengolahan sampah daur ulang & 2 \\
Pengelolaan limbah cair & 2 \\
Pengolahan sampah mudah terurai & 2 \\
Melakukan survei kepuasan kepada penghuni & 2 \\
Mendaftarkan bangunan menjadi Bangunan Hijau & 3 \\
(Greenship Building). & \\
Melibatkan tenaga ahli yang tersertifikasi Greenship & 3 \\
Associate dan tersertifikasi Greenship Professional (GP). & \\
Pembuatan target efisiensi energi dan air & 4 \\
\hline Skor Total & 20 \\
\hline
\end{tabular}

Pekerjaan peningkatan tersebut menghasilkan skor tambahan sebesar 20, sehingga total dari skor awal dan skor tambahan adalah 47. Skor minimum untuk mencapai peringkat bronze adalah 43 sehingga peningkatan tersebut sudah cukup untuk memenuhi predikat bronze untuk kawasan hijau.

Besar anggaran yang diperlukan untuk peningkatan dapat dihitung setelah mengetahui besar volume pada tiap pekerjaan dikalikan dengan harga satuan pekerjaan. Volume pekerjaan seperti diperlihatkan pada Tabel 4.

Tabel 4 Volume pekerjaan peningkatan kawasan hijau

\begin{tabular}{cllr}
\hline No & Pekerjaan & Item & Volume \\
\hline 1. & Pembuatan Ruang Terbuka Hijau & Pembersihan Lahan & $29712 \mathrm{~m}^{2}$ \\
& & Timbunan tanah & $2971 \mathrm{~m}^{3}$ \\
& & Pemasangan Rumput & $29712 \mathrm{~m}^{2}$ \\
& & Pemasangan Pohon Tanjung & $380 \mathrm{bh}$ \\
\hline 2. & Pemasangan Tanaman Lokal & Pemasangan Tanaman Bungur & $986 \mathrm{bh}$ \\
\hline 3. & Pembuatan Trotoar & Pelat Beton 1:2:3 & $408 \mathrm{~m}^{3}$ \\
& & Pas. Ubin Paving Blok & $1020 \mathrm{~m}^{2}$ \\
& & Pemasangan Kanstin & $4080 \mathrm{bh}$ \\
\hline 4. & Penyediaan Tempat Parkir Sepeda & Stand Sepeda & $17 \mathrm{bh}$ \\
\hline 5. & Pembuatan dinding pembatas sungai & Pemasangan Guardrail & $1260 \mathrm{~m}$ \\
\hline 6. & Penyediaan tempat sampah terpilah & Pemasangan tempat sampah & $53 \mathrm{bh}$ \\
\hline
\end{tabular}

Setelah menghitung volume dari setiap pekerjaan, maka anggaran yang dibutuhkan untuk pekerjaan peningkatan dapat dihitung. Besar anggaran biaya pekerjaan didasarkan pada AHSP Kabupaten Jember 2019. Adapun besar anggaran yang diperlukan untuk tiap pekerjaan dapat dilihat pada Tabel 5.

Analisis Investasi Kawasan Hijau Berdasarkan Greenship Neighborhood V.1.0 (Studi Kasus Istana Kaliwates Regency) - Anik Ratnaningsih, Hurrin Ufiantara, Willy Kriswardhana 
Tabel 5 Rencana anggaran biaya peningkatan kawasan hijau (Standar Satuan Harga Edisi 1 Pemerintah Kabupaten Jember, 2019)

\begin{tabular}{|c|c|c|}
\hline No. & Pekerjaan & Biaya \\
\hline 1. & Pembuatan Ruang Terbuka Hijau & Rp 961.962 .604 \\
\hline 2. & Pemasangan Tanaman Lokal & 35.516 .016 \\
\hline 3. & Pembuatan Trotoar & Rp 3.248.807.981 \\
\hline 4. & Penyediaan Tempat Parkir Sepeda & 6.856 .879 \\
\hline 5. & Pembuatan dinding pembatas sungai & Rp 574.312 .608 \\
\hline \multirow[t]{2}{*}{6.} & Penyediaan tempat sampah terpilah & 80.166 .651 \\
\hline & Total RAB & Rp 4.907.622.738 \\
\hline
\end{tabular}

Didapat besar rencana anggaran biaya untuk peningkatan kawasan hijau sebesar Rp 4.907.622.738,-.

\section{Hasil dan Pembahasan}

\subsection{Kenaikan Harga}

Perubahan harga jual rumah didasarkan pada berkurangnya jumlah rumah karena diubah menjadi RTH dan penambahan fasilitas greenship pada kawasan perumahan.

Salah satu faktor yang dijadikan acuan dalam penentuan kenaikan harga jual rumah yaitu dengan menghitung kerugian. Kerugian yang dimaksud adalah besarnya profit yang hilang karena berkurangnya unit rumah yang akan dijual karena dijadikan lahan RTH. Besar kerugian dapat dilihat pada Tabel 6.

Tabel 6 Besar kerugian akibat peningkatan greenship

\begin{tabular}{clrlll}
\hline No & \multicolumn{1}{c}{ Uraian } & \multicolumn{2}{c}{ Menjadi RTH } & \multicolumn{2}{c}{ Kerugian } \\
\hline A. & Harga Jual & & & & \\
& Tipe 43/72 & 156 & Unit & $\mathrm{Rp}$ & 42.900 .000 .000 \\
& Tipe 45/72 & 213 & Unit & $\mathrm{Rp}$ & 60.066 .000 .000 \\
\hline B. & Biaya Konstruksi & & & & \\
& Tipe 43/72 & 156 & Unit & $\mathrm{Rp}$ & 11.403 .600 .000 \\
& Tipe 45/72 & 213 & Unit & $\mathrm{Rp}$ & 16.294 .500 .000 \\
\hline C. & Biaya Pembebasan Lahan & & & \\
& Tipe 43/72 & 156 & Unit & $\mathrm{Rp}$ & 5.616 .000 .000 \\
& Tipe 45/72 & 213 & Unit & $\mathrm{Rp}$ & 7.668 .000 .000 \\
\hline D. & Total Kerugian $(\mathrm{A}-(\mathrm{B}+\mathrm{C}))$ & & $\mathrm{Rp}$ & 61.983 .900 .000 \\
\hline
\end{tabular}

Diketahui total kerugian sebesar Rp 61.983.900.000,- Setelah mengetahui besar kerugian, dilakukan perhitungan untuk mencari luas lahan rumah yang tersisa. Luas lahan rumah yang tersisa dapat dilihat pada Tabel 7.

Tabel 7 Luas lahan tersisa

\begin{tabular}{clrlrl}
\hline No & \multicolumn{1}{c}{ Tipe } & Jumlah & \multicolumn{2}{c}{ Total Luas } \\
\hline 1. & $43 / 72$ & 263 & Unit & 18936 & $\mathrm{~m}^{2}$ \\
2. & $45 / 72$ & 282 & Unit & 20304 & $\mathrm{~m}^{2}$ \\
3. & $90 / 120$ & 72 & Unit & 8640 & $\mathrm{~m}^{2}$ \\
\hline \multicolumn{3}{l}{} & Luas Lahan Rumah Tersisa \\
\hline
\end{tabular}

Analisis Investasi Kawasan Hijau Berdasarkan Greenship Neighborhood V.1.0 (Studi Kasus Istana Kaliwates Regency) - Anik Ratnaningsih, Hurrin Ufiantara, Willy Kriswardhana 
Diketahui luas lahan rumah yang tersisa seluas $47880 \mathrm{~m}^{2}$. Setelah mengetahui besar kerugian dengan luas lahan, maka besar kenaikan harga dapat ditentukan sebagai berikut:

$$
\text { Kemaikan Harga } / m^{2}=\frac{\text { Easat Kurugiatm }}{\text { luas lakath Rutmak }}
$$

Dari persamaan 1 dapat dihitung besar kenaikan harga tiap $\mathrm{m}^{2}$ adalah $\mathrm{Rp} 1.294 .568 / \mathrm{m}^{2}$ atau dibulatkan menjadi Rp $1.300 .000 / \mathrm{m}^{2}$. Kenaikan harga didasarkan pada luas lahan tanah. Perubahan harga jual tiap tipe rumah seperti dipelihatkan pada Tabel 8 .

Tabel 8 Perubahan harga jual rumah

\begin{tabular}{cccc}
\hline No & Tipe & Harga Awal & Harga Akhir \\
\hline 1. & $43 / 72$ & $\mathrm{Rp} 275.000 .000$ & $\mathrm{Rp} \mathrm{368.600.000}$ \\
2. & $45 / 72$ & $\mathrm{Rp} 282.000 .000$ & $\mathrm{Rp} 375.600 .000$ \\
3. & $90 / 120$ & $\mathrm{Rp} 775.000 .000$ & $\mathrm{Rp} 931.000 .000$ \\
\hline
\end{tabular}

\subsection{Besar Penjualan}

Besar penjualan dapat ditentukan dari besar okupansi penjualan dan unit rumah yang akan dijual. Besar okupansi didapat dari kuesioner minat beli konsumen yang dapat dilihat pada Gambar 2.

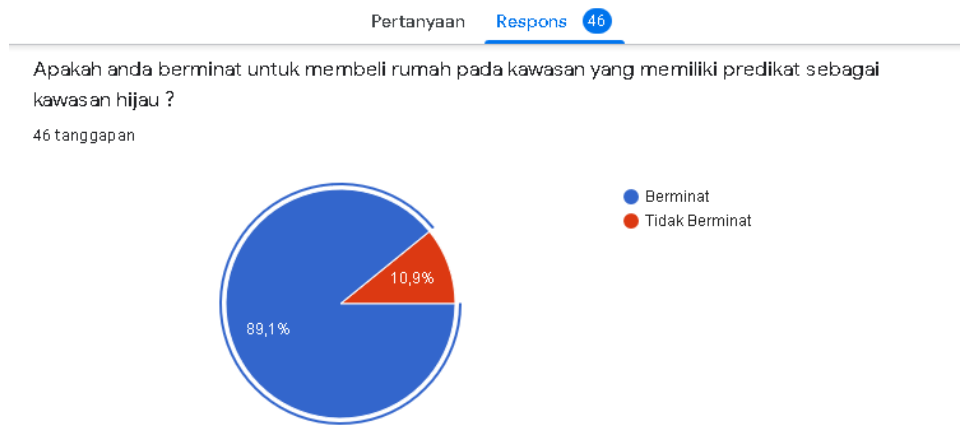

Gambar 2 Hasil survey terhadap minat beli rumah kawasan hijau

Diagram tersebut diketahui besar okupansi penjualannya adalah $89,1 \%$. Setelah mengetahui besar okupansi, maka estimasi penjualan tiap tahunnya dapat ditentukan. Umur investasi direncanakan selama 5 tahun. Estimasi penjualan per tahun dapat dilihat pada Tabel 9.

Tabel 9 Estimasi penjualan tiap tahun

\begin{tabular}{|c|c|c|c|c|}
\hline \multirow{2}{*}{ No } & \multirow{2}{*}{ Tipe } & \multirow{2}{*}{ Jumlah Kavling } & \multicolumn{2}{|c|}{ Estimasi Terjual } \\
\hline & & & 5 tahun & Per tahun \\
\hline \multirow[t]{4}{*}{ A } & RUMAH & & & \\
\hline & $42 / 72$ & 263 & 235 & 47 \\
\hline & $45 / 72$ & 282 & 252 & 51 \\
\hline & $90 / 120$ & 72 & 65 & 9 \\
\hline \multirow[t]{2}{*}{ B } & RUKO & & & \\
\hline & 50 & 13 & 12 & 3 \\
\hline $\begin{array}{l}\text { Analisi } \\
\text { Kasus } \\
\text { Kriswa }\end{array}$ & $\begin{array}{l}\text { estasi Kawa } \\
\text { na Kaliwate } \\
\text { na }\end{array}$ & $\begin{array}{l}\text { u Berdasarkan Gree } \\
\text { cy) - Anik Ratnan }\end{array}$ & $\begin{array}{l}\text { eighborhoc } \\
\text { Hurrin Uf }\end{array}$ & $\begin{array}{ll}\text { Studi } & 23 \\
\text { Willy }\end{array}$ \\
\hline
\end{tabular}




\subsection{Penyusunan Cash Flow}

Penyusunan cash flow dilakukan dengan merencanakan cash in-flow dan cash out-flow terlebih dahulu. Cash out-flow dibagi menjadi biaya tetap dan biaya variabel. Biaya tetap pada penelitian ini adalah pembebasan lahan dan RAB peningkatan kawasan hijau, sedangkan biaya variabelnya adalah biaya produksi unit rumah. Biaya pembebasan lahan dapat dilihat pada Tabel 10.

Tabel 10 Biaya pembebasan lahan kawasan perumahan

\begin{tabular}{|c|c|c|}
\hline No & Tipe & Total Biaya Pembebasan \\
\hline A & Lahan Rumah & Rp 37.224.000.000 \\
\hline $\mathrm{B}$ & Lahan Ruko & 325.000 .000 \\
\hline C. & Pembebasan Lahan Fasilitas umum dan sosial (31\%) & Rp 16.869 .840 .580 \\
\hline $\mathrm{D}$ & Pembebasan Lahan Total $(\mathrm{A}+\mathrm{B}+\mathrm{C})$ & Rp 54.418.840.580 \\
\hline
\end{tabular}

Diketahui besar biaya yang diperlukan untuk pembebasan lahan adalah sebesar Rp 54.418.840.580,-. Adapun biaya produksi rumah tiap tahunnya dapat dilihat pada Tabel 11.

Tabel 11 Biaya produksi unit rumah tiap tahun

\begin{tabular}{clcrr}
\hline No & \multicolumn{1}{c}{ Tipe } & Estimasi Terjual & \multicolumn{2}{c}{ Total Biaya } \\
\hline A & RUMAH & 47 Unit & & \\
& $43 / 72$ & Rp & 3.435 .700 .000 \\
& $45 / 72$ & 13 Unit & Rp & 3.901 .500 .000 \\
& $90 / 120$ & & $\mathrm{Rp}$ & 1.989 .000 .000 \\
\hline B & RUKO & 3 Unit & Rp & 345.000 .000 \\
& 50 & BIAYA PRODUKSI TIAP TAHUN $(\mathrm{A}+\mathrm{B})$ & $\mathrm{Rp}$ & 9.671 .200 .000 \\
\hline C & BIA
\end{tabular}

Diketahui biaya variabel untuk produksi tiap tahunnya membutuhkan Rp9.671.200.000,--.

Cash In-Flow pada penelitian ini adalah besar penjualan unit rumah tiap tahunnya. Nilai cash in-flow dapat dilihat pada Tabel 12.

Tabel 12 Penjualan tiap tahun

\begin{tabular}{lllll}
\hline No & \multicolumn{1}{c}{ Tipe } & \multicolumn{2}{c}{ Estimasi Terjual } & Penjualan / tahun \\
\hline $\mathrm{A}$ & RUMAH & & & \\
& $43 / 72$ & 47 & Unit & Rp 17.324 .200 .000 \\
& $45 / 72$ & 51 & Unit & Rp 19.155 .600 .000 \\
& $90 / 120$ & 13 & Unit & Rp 12.103 .000 .000 \\
\hline B & RUKO & & & \\
& 50 & 3 & Unit & Rp 2.490 .000 .000 \\
\hline C & PENJUALAN PER TAHUN (A+B) & Rp 51.072.800.000 \\
\hline
\end{tabular}

Diketahui besar pemasukan tiap tahunnya sebesar Rp 51.072.800.000,-. Setelah menentukan besar cash in-flow dan cash out-flow maka cash flow dapat dibuat. Penelitian ini menggunakan suku bunga $15 \%$ dan umur investasi selama 5 tahun. Pinjaman awal sebesar R60.000.000.000,- dengan jangka waktu pelunasan selama 5 tahun. Besar aliran kas dapat dilihat pada Gambar 5 sampai Gambar 8.

Analisis Investasi Kawasan Hijau Berdasarkan Greenship Neighborhood V.1.0 (Studi Kasus Istana Kaliwates Regency) - Anik Ratnaningsih, Hurrin Ufiantara, Willy Kriswardhana 


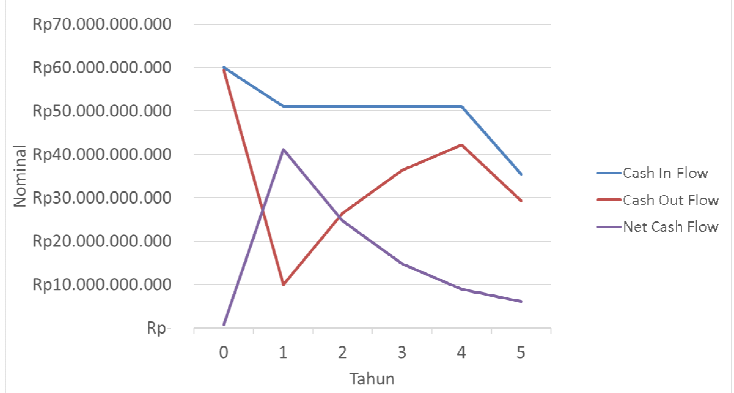

Gambar 5 Arus kas tiap tahun

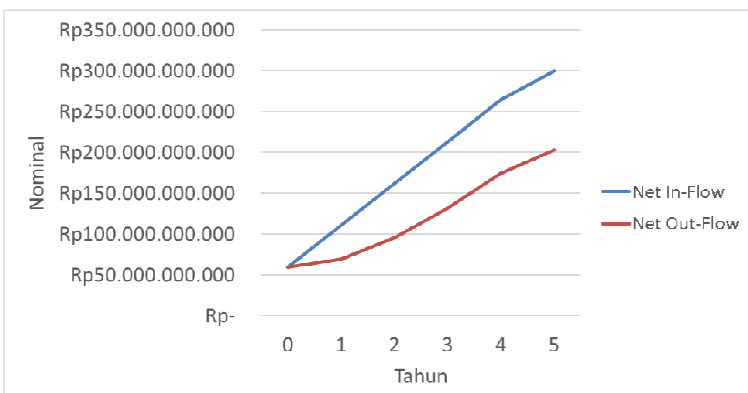

Gambar 6 Arus kas kumulatif

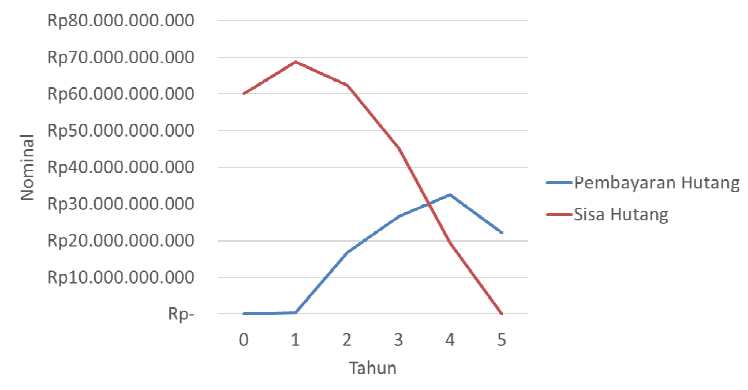

\section{Gambar 7 Pelunasan hutang}

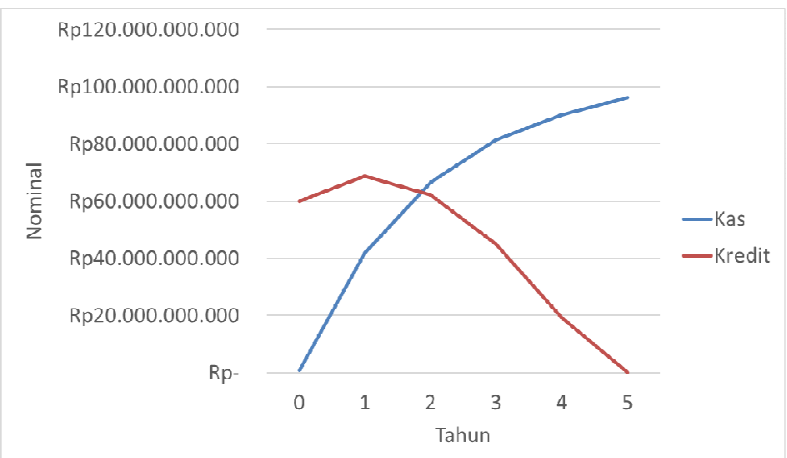

Gambar 8 Total kas dan kredit tiap tahun

Analisis Investasi Kawasan Hijau Berdasarkan Greenship Neighborhood V.1.0 (Studi Kasus Istana Kaliwates Regency) - Anik Ratnaningsih, Hurrin Ufiantara, Willy Kriswardhana 


\subsection{Analisis Investasi Kawasan Hijau}

Setelah membuat Cash Flow, maka dapat dilakukan penilaian untuk menentukan kelayakan investasi. Penelitian ini menggunakan 5 metode untuk menentukan kelayakan investasi, yaitu NPV, IRR, BEP, PBP, dan PI yang akan dijabarkan sebagai berikut:

1. Net Present Value, ditentukan dengan menggunakan bunga tahunan sebesar 15\% dan usia investasi selama 5 tahun. Tabel perhitungan NPV dapat dilihat pada Tabel 13.

\section{Tabel 13 Perhitungan NPV}

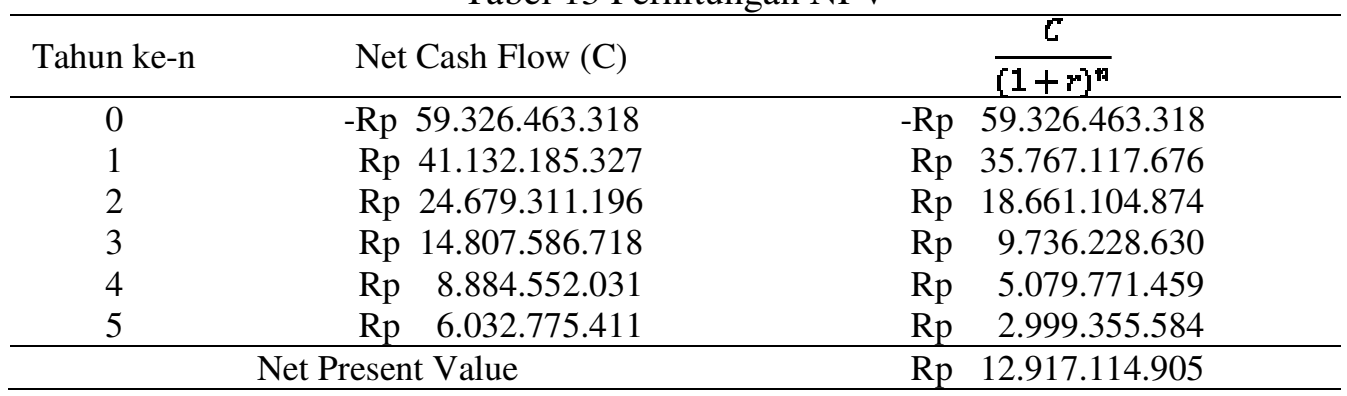

Diketahui nilai Net Present Value lebih besar dari nol, maka investasi dikatakan layak.

2. Internal Rate of Return dapat diketahui dengan cara menginterpolasikan NPV bernilai positif dengan NPV bernilai negatif, untuk mencari suku bunga dengan nilai NPV sama dengan nol. Diketahui NPV bernilai positif sebesar Rp12.917.114.905,- dengan suku bunga 15\%, dan NPV bernilai negatif sebesar Rp1.607.735.570,- dengan suku bunga 30\%. Besar IRR dapat diketahui dengan rumus berikut. (Faqih, 2018)

$$
I R R=r_{\mathrm{L}}+\frac{\mathrm{NFv_{1 }}}{N P V_{1}-N P \gamma_{2}}\left(r_{2}-r_{1}\right)
$$

Dengan menggunakan Rumus 2 didapatkan besar IRR adalah 28,34\%. Karena IRR lebih besar dari suku bunga tahunan (15\%) maka investasi dikatakan layak.

3. Break Even Point, didapatkan dari biaya tetap dibagi dengan profit tiap tahunnya. Break Even Point dalam unit dan harga dapat diketahui dengan menggunakan rumus berikut: (Darmawan, 2019)

$$
\begin{aligned}
& \text { BEP hurgu }-\frac{\pi c}{\left.1-i \frac{v C}{\rho}\right)} \\
& B E P \text { umit }=\frac{\pi c}{p-v \tau}
\end{aligned}
$$

Didapat nominal pengembalian yang diperlukan untuk mencapai BEP adalah sebesar Rp73.184.818.841,- dan penjualan minimum 68 unit rumah tipe 43/72,

Analisis Investasi Kawasan Hijau Berdasarkan Greenship Neighborhood V.1.0 (Studi Kasus Istana Kaliwates Regency) - Anik Ratnaningsih, Hurrin Ufiantara, Willy Kriswardhana 
74 unit rumah tipe 45/72, 19 unit rumah tipe 90/120, dan 5 unit ruko. Karena besar penjualan saat mencapai BEP kurang dari total unit yang ada, maka investasi dikatakan layak.

4. Payback Period didapat dari besar investasi awal dibagi dengan arus kas tiap tahunnya. Besar investasi awal pada penelitian ini yaitu Rp60.000.000.000. Perhitungan Payback Period menggunakan rumus berikut (Darmawan, 2019):

$$
\text { Payback Period }=\frac{\text { NiLri Jnurastagi }}{\text { Patnasukan Bargih }}
$$

Didapat besar pengembalian dengan Payback Period adalah 1,449 tahun atau dibulatkan menjadi 2 tahun. Karena PBP kurang dari usia rencana investasi (5tahun) maka investasi dikatakan layak.

5. Profit Ability Index didapat dari akumulasi total aliran kas masuk dibagi dengan modal awal investasi (Bringham and Houston, 2014). Modal awal investasi pada penelitian ini yaitu Rp60.000.000.000,- dengan total aliran kas masuk Rp95.536.410.683,-. Didapat nilai PI sebesar 1,592, karena lebih besar daripada 1 (satu) maka investasi dikatakan layak.

\section{Kesimpulan dan Saran}

\subsection{Kesimpulan}

Berdasarkan hasil analisis perhitungan yang telah dilakukan, dapat diambil kesimpulan.

1. Total Anggaran Biaya yang diperlukan untuk meningkatkan peringkat greenship kawasan rumah menjadi bronze adalah Rp 4.907.622.738,-

2. Analisis investasi menunjukkan Net Present Value sebesar Rp12.917.114.905,sehingga investasi dapat dikatakan layak karena NPV bernilai lebih dari nol. Analisis dengan Internal Rate of Return diketahui sebesar 28,34\%, lebih besar dari suku bunga tahunan $15 \%$ sehingga investasi juga layak secara metode IRR.Analisis dengan Profit Ability Index menunjukkan angka 3,449 sehingga investasi juga layak secara metode PI karena menunjukkan hasil lebih dari 1 (satu).

3. Pengembalian modal yang dibutuhkan untuk mencapai Break Even Point adalah sebesar Rp73.184.818.841,- dengan penjualan minimum 68 unit rumah tipe 43/72, 74 unit rumah tipe 45/72, 19 unit rumah tipe 90/120, dan 5 unit ruko. Waktu yang diperlukan untuk pengembalian modal dengan Payback Period adalah 2 tahun sehingga investasi dapat dikatakan layak karena lama pengembalian kurang dari jangka investasi selama 5 tahun.

\subsection{Saran} berikut:

Saran yang diberikan untuk meningkatkan kualitas tulisan ini adalah sebagai

1. Analisis Investasi perlu memperhatikan adanya inflasi dan ketidakpastian yang dapat memengaruhi nilai investasi.

Analisis Investasi Kawasan Hijau Berdasarkan Greenship Neighborhood V.1.0 (Studi Kasus Istana Kaliwates Regency) - Anik Ratnaningsih, Hurrin Ufiantara, Willy Kriswardhana 
2. Perlu adanya studi lanjutan tentang minat pembeli untuk tipe rumah dan harga yang berbeda.

3. Perlu dilakukan survey untuk mengetahui minat konsumen apabila harga rumah mengalami peningkatan akibat penerapan konsep hijau.

\section{Daftar Kepustakaan}

Aulia, R. (2014) 'Pengaruh Permintaan Pasar Terhadap Rumah Berkonsep Hijau di Citraland Surabaya'.

Bringham, E. F. and Houston, J. F. (2014) Fundamental of Financial Management.

Darmawan, M. I. (2019) Analisis Biaya Dan Penetapan Harga Pokok Sewa Mall Pada Jember Town Square. Universitas Jember.

Faqih, M. A. A. (2018) Analisis Biaya Dan Permintaan Dalam Penetapan Harga Pokok Penjualan Unit Apartemen Jember Town Square. Universitas Jember.

Green Building Council Indonesia (2015) 'Greenship Neighborhood V.1.0'.

Jember, B. (2019) Standar Satuan Harga Edisi 1 Pemerintah Kabupaten Jember.

Manggiasih, N. V., Hakim, L. and Siswoyo, E. (2019) 'Kajian Greenship Kawasan GBCI Versi 1.0 Studi Kasus $\square$ : Kawasan Scientia Garden', Jurnal Teknik Lingkungan UII, pp. 1-11.

Ronim, A. and Talidah, C. I. (2019) 'Pengkuran Greenship Kawasan (Built Project) Versi 0.1 pada Kawasan Wisata Bandar Ecopark di Kabupaten Batang', Jurnal Arsitektur ARCADE. doi: 10.31848/arcade.v3i1.174.

Copyright (c) Anik Ratnaningsih, Hurrin Ufiantara, Willy Kriswardhana,

Analisis Investasi Kawasan Hijau Berdasarkan Greenship Neighborhood V.1.0 (Studi Kasus Istana Kaliwates Regency) - Anik Ratnaningsih, Hurrin Ufiantara, Willy Kriswardhana 